\title{
Ontogenesis, structure and ultrastructure of Hymenaea stigonocarpa (Fabaceae: Caesalpinioideae) colleters
}

\author{
Élder Antônio Sousa Paiva ${ }^{1}$ \& Silvia Rodrigues Machado ${ }^{2}$ \\ 1 Universidade Federal de Minas Gerais, Instituto de Ciências Biológicas, Depto. Botânica, 31270-901 - Belo \\ Horizonte, MG, Brazil; epaiva@icb.ufmg.br \\ 2 Universidade Estadual Paulista Julio de Mesquita Filho, Instituto de Biociências, Depto. Botânica, CP 510, 18618-000 \\ - Botucatu, Sao Pablo, Brazil.
}

Received 04-XII-2003. C Corrected 13-IX-2005. Accepted 15-III-2006.

\begin{abstract}
The genus Hymenaea is characterized by a great diversity of secretory structures, but there are no reports of colleters yet. The objectives of this study are to report the occurrence and describe the origin and structure of colleters in Hymenaea stigonocarpa Mart. ex Hayne. Shoot apex samples were collected, fixed, and processed for light microscopy, scanning electron microscopy, and transmission electron microscopy as per usual methods. Colleters occur predominantly on the stipule's adaxial side. These structures are found at the base on a narrow strip, corresponding to the median vein up to half the length of the stipule. When present on the abaxial side, they are concentrated at the base and restricted to the margins. Colleters develop from the protoderm; they are elongate and club-shaped. Their body has no stratification; their surface cells differ from the inner cells only in position and presence of cuticle. Colleter cells have thin walls, dense cytoplasm, large nuclei, many mitochondria, rough endoplasmic reticulum, and abundant dictyosomes. Histochemical tests with Ruthenium red showed pectic compounds in the cytosol. In $H$. stigonocarpa, colleter arrangement is compatible with the hypothesis that they protect shoot apex. In this species, protection is reinforced by the sheath formed by the stipule pairs. Rev. Biol. Trop. 54 (3): 943-950. Epub 2006 Sept. 29.
\end{abstract}

Key words: “Cerrado” vegetation, colleter, secretion, stipule, ultrastructure.

Colleters are considered to be glandular trichomes that produce a mucilaginous or resinous substance and are present in the shoot apex (Fahn 1990). These structures differentiate early and their function is to protect the shoot meristem and leaf primordia (Mueller 1985, Thomas and Dave 1990, Thomas 1991). Colleters have been interpreted as emergences; ligules and specialized hairs, among others (Thomas 1991). These structures show a great diversity of form, however, their anatomical structure is a relatively simple one: they are usually small and non-vascularized. On the basis of their position, structural or morphological identity with other secretory structures, several other terms have been attributed to the colleters; glands, glandular hairs and extrafloral nectaries (Thomas 1991).

A number of Angiosperm families (Thomas 1991) contain colleters but, as far as we know, there are no reports of their occurrence in the Fabaceae-Caesalpinioideae. This study presents the first record of colleters in the genus Hymenaea, a member of the FabaceaeCaesalpinioideae. This genus contains about 13 species in tropical America and is characterized by a great diversity of secretory structures, including nectaries and resin secretory cavities (Lee and Langenheim 1975). Hymenaea stigonocarpa is a $5 \mathrm{~m}$ tall tree commonly seen in Brazilian "Cerrado" vegetation. We describe the occurrence, origin, distribution, and structure of colleters in this species. 


\section{MATERIALS AND METHODS}

Shoot apices were collected from adult $H$. stigonocarpa plants from the Botucatu "Cerrado" vegetation, São Paulo, Brazil. Fertile branches were sampled and deposited as voucher specimens in the Herbário "Irina D. Gemtchújnicov” (BOTU) Herbarium of the Department of Botany, Botucatu Institute of Biosciences, UNESP, under numbers 23132 and 23 133, and 23189 to 23191.

For light microscopy, samples were fixed in Karnovsky solution (Karnovsky 1965), dehydrated by ethanol (Johansen 1940), and embedded in glycol-methacrylate historesin, as per standard methods. Longitudinal and transverse $5 \mu \mathrm{m}$-thick sections were stained with toluidine blue (O'Brien et al. 1964) and mounted using synthetic Canadian balsam. The following histochemical tests were performed: Sudan IV for lipids; $10 \%$ aqueous ferric chloride to locate phenolic compounds; and Ruthenium red solution to detect pectic compounds (Johansen 1940).

For transmission electron microscopy (TEM), colleters from the two outermost stipule pairs, here referred as P4 (the outermost) and P3 (the innermost), were sampled. They were fixed in Karnovsky solution (Karnovsky 1965) for $24 \mathrm{~h}$, post-fixed in 1\% osmium tetroxide (0.1 M, pH 7.2, phosphate buffer) for $2 \mathrm{~h}$, dehydrated by acetone series, and embedded in Araldite (Roland 1978). Ultra-thin sections were stained with uranyl acetate and lead citrate (Roland 1978) and examined by Philips CM 100 TEM at $60 \mathrm{KV}$.

For scanning electron microscopy (SEM), samples were fixed as above, dehydrated by increasing ethyl alcohol series and critical point dried using $\mathrm{CO}_{2}$. The samples were goldcoated as per Robards (1978) and examined by Philips 515 SEM.

\section{RESULTS}

In $H$. stigonocarpa, the shoot apex is protected by a pair of stipules; these are pubescent on the adaxial side and are strongly bound by the margins due to trichome interlacing. Each pair of stipules protects a leaf primordium, and an innermost pair of stipules, which in turn protects a second leaf primordium and another pair of stipules; this is successively repeated (Fig. 1). These stipules are deciduous, becoming detached at the time of leaf growth.

Colleters occur exclusively on the stipules between trichomes (Fig. 3). On the adaxial side, the colleters are abundant and occur at the base in a narrow strip, corresponding to the median vein up to half the length of the stipule (Fig. 2). On the abaxial side, they are rare and concentrated at the base and restricted to the margins. In this species the colleters are translucent.

The beginning of colleter differentiation can be seen in the younger stipules, that is, those closer to the apical meristem (Fig. 1, 5, $6)$. Initially, groups of protoderm cells of the stipule elongate anticlinally and form dense cytoplasm and large nuclei (Fig. 5). A colleter develops from continued divisions of these cells (Fig. 5-8).

$H$. stigonocarpa colleters are non-vascularized, elongated, club-shaped with a striated surface (Fig. 3, 4, 7, 8); their body has no stratification; the superficial cells differ from the inner ones only by their position and the presence of a thin cuticle (Fig. 4, 7).

All cells of the colleter body reacted positively to Ruthenium red indicating the presence of pectic compounds in the cytosol and intercellular spaces. Phenolic compounds are abundant in non-secretory basal cells; there are occasionally small quantities of these compounds in the vacuole of secretory cells. Lipids stained by Sudan IV seem to be restricted to those structural ones; the cytoplasm accumulation of these compounds has not been detected in secretory cells. In the adult colleter, basal cells are highly vacuolated and have thick walls (Fig. 7, 8) in which lipid substances and lignin were stained by Sudan IV and acidified fluroglucin, respectively.

In colleters of the innermost stipule pair (P3) the cells have thin walls; dense cytoplasm; 

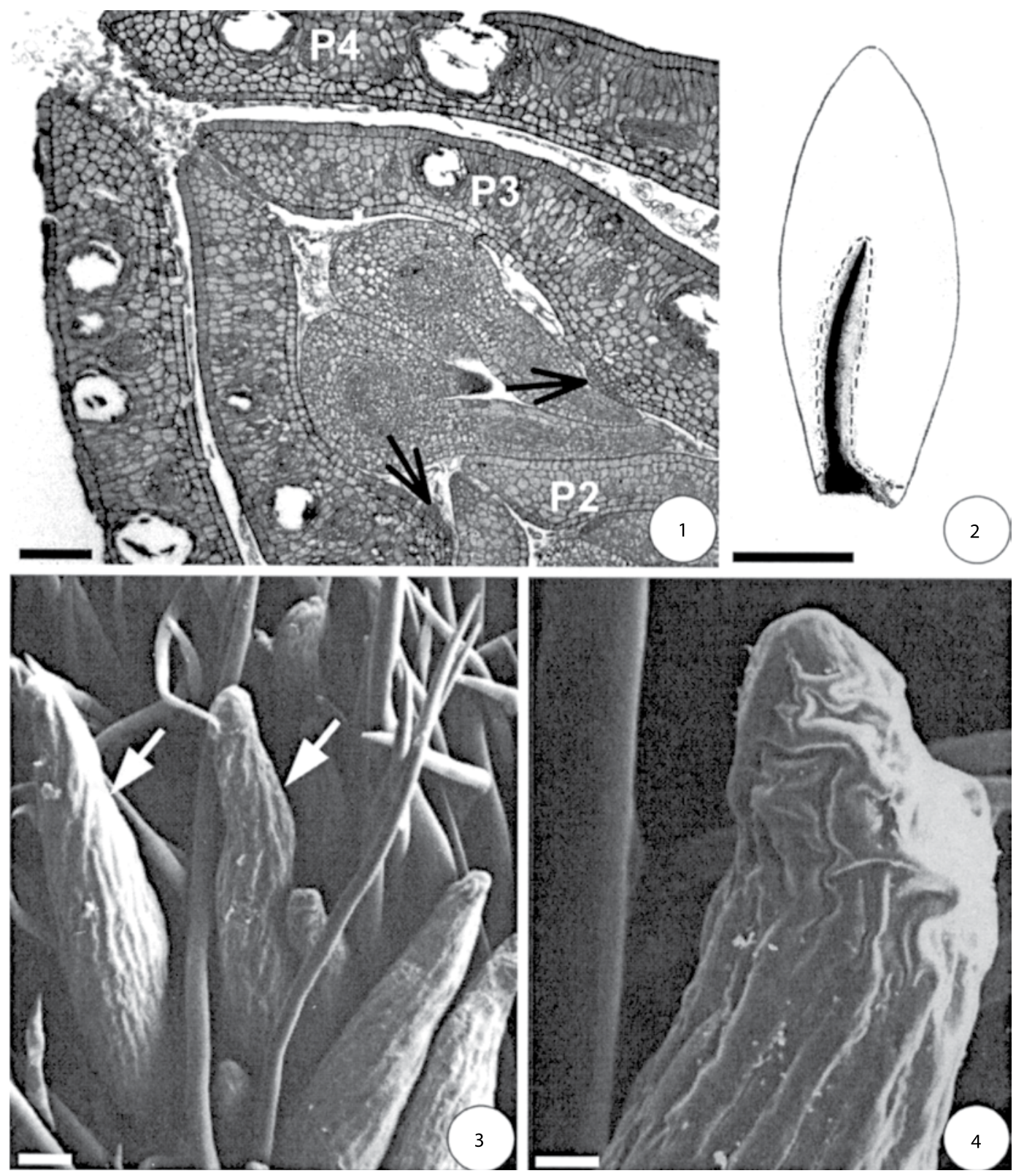

Fig. 1-4. 1. Shoot apex transverse section; Note alternate stipules protecting the leaf primordia, trichomes density at the stipule margins, and bulging (arrows) corresponding to median vein where colleters occur; P4-P2 outermost to innermost stipules pairs. 2. Drawing showing the adaxial side of the stipule, the colleters occur in the dotted area. 3. Colleters (arrows) on the stipule adaxial side. 4. Colleter apical portion, note flaccid cuticle resulting from secretion accumulation. Bar=100 $\mu \mathrm{m}$ (1); 10 mm (2); $50 \mu \mathrm{m}$ (3);10 $\mu \mathrm{m}$ (4). 

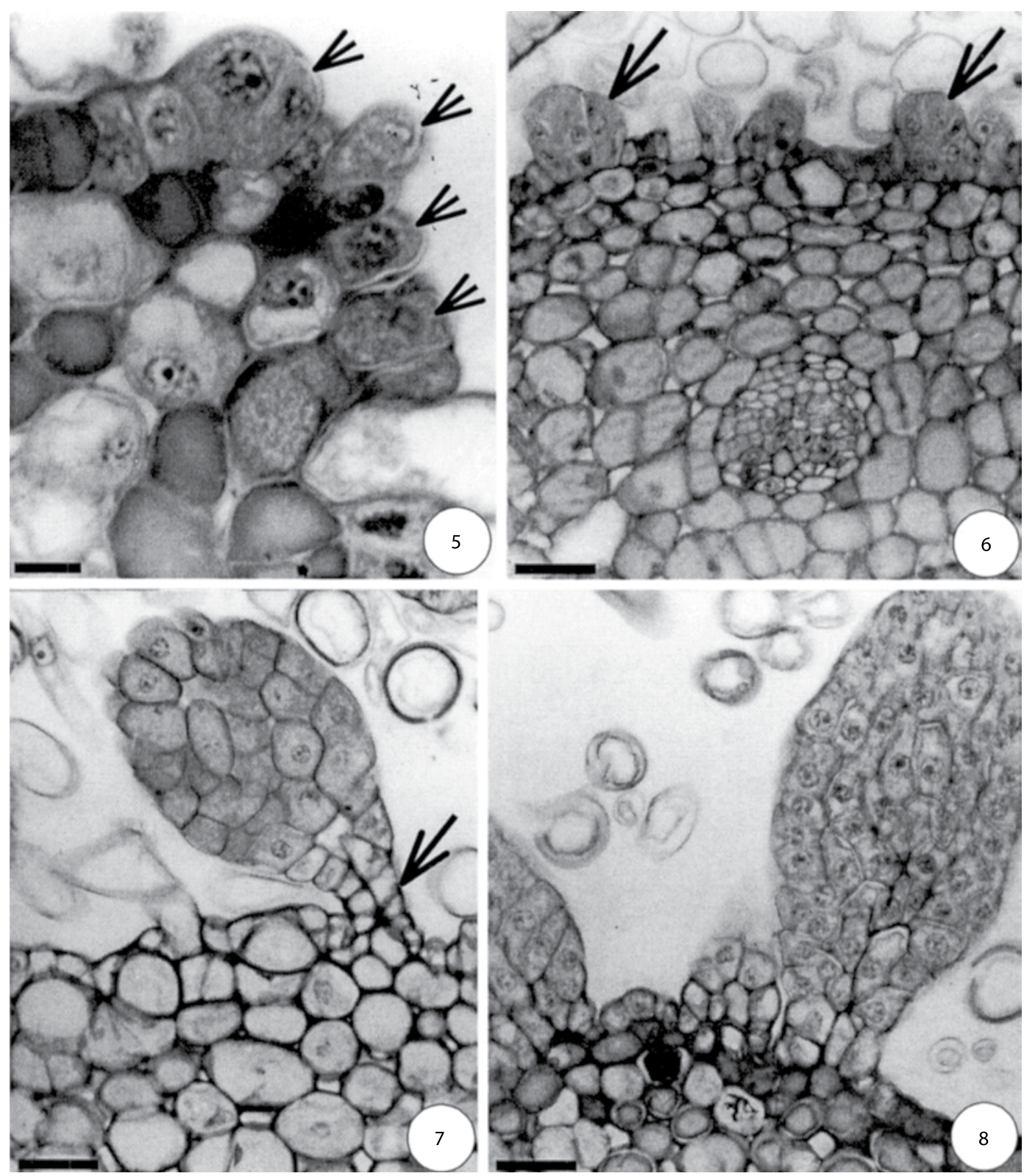

Fig. 5-8. 5-6. Stipule transverse section showing colleter precursor cells (arrows) on the epidermis. 7. Median longitudinal section of young colleter, note marked thickening of basal cell walls (arrow). 8. Adult colleter, note dense cytoplasm and poorly developed vacuome. Bar = $10 \mu \mathrm{m}$ (5); $25 \mu \mathrm{m}$ (6-8).

large nuclei; numerous mitochondria with welldeveloped cristae; dictyosomes and smooth endoplasmic reticulum (SER) (Fig. 9-11). A large number of vesicles from the reticulum and the dictyosomes are seen distributed throughout the cytosol. The endoplasmic reticulum (ER) can be seen as relatively long segments near the plasma membrane (Fig. 9-10). In the colleter cells, there is a well-developed periplasmatic space (Fig. 11-12). In these cells, the vacuoles are small and some of them present an inner membrane system (Fig. 9-10). 

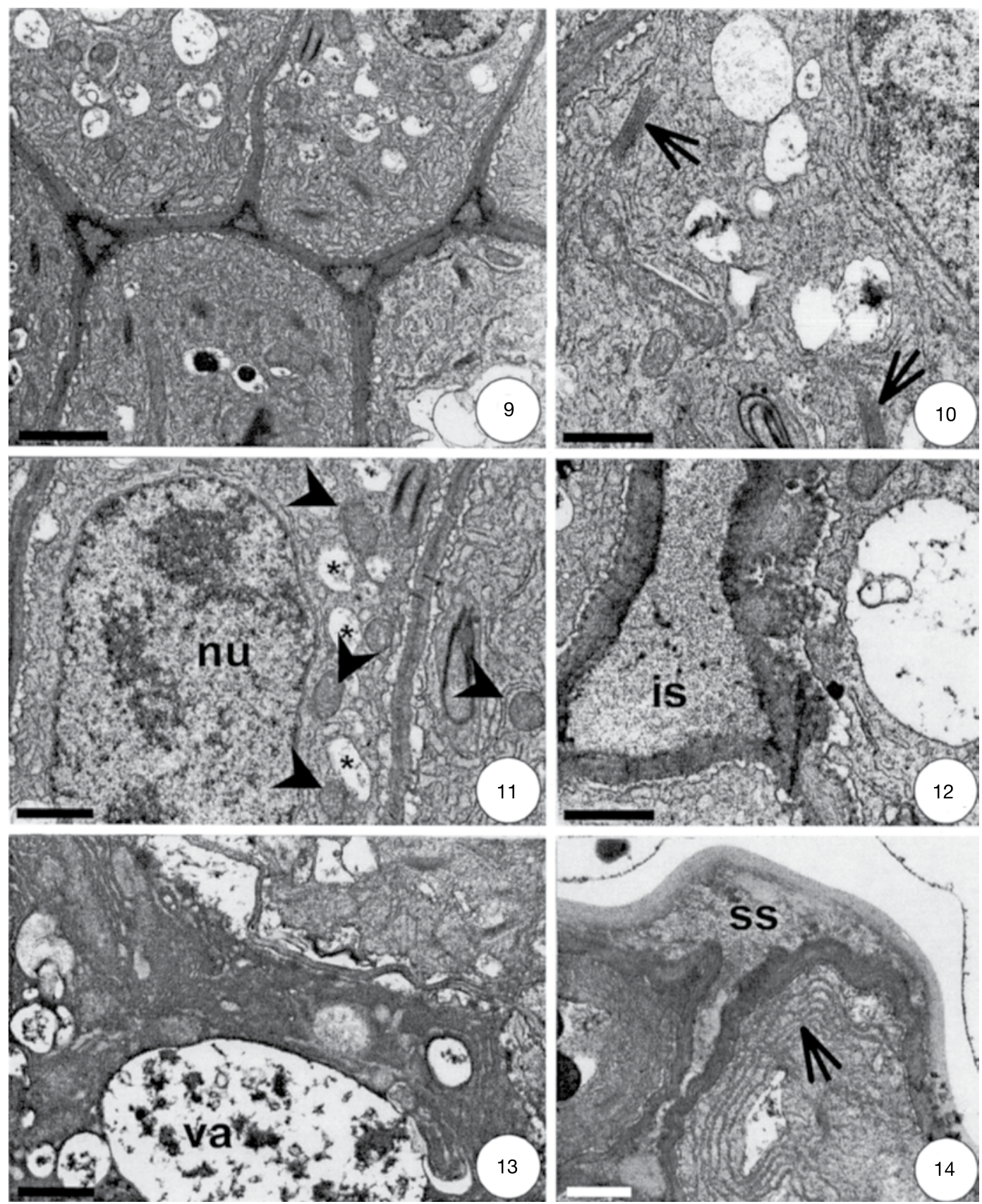

Figs. 9-14. Colleter body secretory cells. 9-10. Note the dense cytoplasm and the presence of well-developed dictyosomes and RER segments, in 10 arrows indicate dictyosomes. 11. Detail showing mitochondria (arrowhead), small vacuoles $\left({ }^{*}\right)$, and large nucleus (nu). 12. Note the intercellular space (is) with secretion. 13. Cell in advanced lysis stage, note the presence of autophagic vacuole (va) and cytosol darkening. 14. Note secretion accumulation in intercellular and subcuticular spaces (ss); in the peripheral cytoplasm note abundant RER segments (arrow). Bar= $2 \mu \mathrm{m}$ (9); $1 \mu \mathrm{m}$ (10-14). 
On the outermost stipule pair (P4), the colleters close to senescence show cells with sinuous walls and dense cytoplasm. In these cells, there is an increase in the number of dictyosomes and endoplasmic reticulum (RER). The RER segments are parallel to the plasma membrane forming stacks (Fig. 13, 14). The vacuoles show more phenolic compounds compared to the previous phase.

Secretion accumulates in the intercellular spaces between the epithelial cells and in the subcuticular space (Fig. 14). In the epithelial colleter cells, the middle lamella of the anticlinal walls degrades; this allows cell separation and space formation (Fig. 12, 14). The subcuticular space is formed by cuticle displacement (Fig. 14).

Colleters of the outermost stipule show some cells with cytoplasm darkening, nuclear chromatin condensation, large vacuoles resulting from vacuole fusion, and a reduction in the number of organelles (Fig. 13).

\section{DISCUSSION}

In $H$. stigonocarpa, stipules encase the innermost stipule and the young leaf in a repetitive pattern, thus protecting successive leaf primordia and the shoot apex, in a rare arrangement (Lee and Langenheim 1975); this indicates the protective role of these structures as suggested by Lubbock (1890). The presence of colleters in these stipules suggests that their main role is protection of shoot apex and leaf primordia (Mueller 1985, Thomas 1991).

According Thomas (1991) the colleters are exclusively found on the adaxial side of the organs and their presence in stipules is quite common. Colleters are also seen on the abaxial side of $H$. stigonocarpa stipules; this may be related to the arrangement of stipules in this species. In the shoot apex of $H$. stigonocarpa, the innermost stipules are protected by the outermost ones. Thus colleter secretion products on the abaxial side are secreted into the space between the stipules where there is a leaf primordium to protect it.
The fact that $H$. stigonocarpa colleters are exclusively of protodermic origin allows them to be characterized as trichomes, as per Solereder (1908). Colleters of exclusively protodermic origin seem to be rare; the most common are those where formation cells of the ground meristem and even the vascular system participate (Thomas 1991) The cells of $H$. stigonocarpa colleters are structurally uniform differing only in their position in the colleter, except for the basal cells, which stand out by presenting a large vacuole and lignified walls. Colleters of protodermic origin were also observed by Rocha et al. (2002) in Hibiscus (Malvaceae) species.

The abundance of both SER and RER was also described by Mohan and Inamdar (1986) in Plumeria rubra colleters. In $H$. stigonocarpa young colleters, these organelles may be involved in terpene synthesis, one of the colleter secretion components (Fahn 1990), as in this phase the SER predominates.

In $H$. stigonocarpa colleters of the outermost stipule pairs, secretion accumulation in intercellular spaces and ultrastructural characteristics are compatible with the secretory activity, although the presence of dark cytoplasm cells and nuclear chromatin condensation are evidence of programmed cell death (Schussler and Longstreth 1996). In this phase, dark cytoplasm cells were seen alongside those without this characteristic, indicating that this cytoplasm darkening is not the result of technical artifact, but a normal event in the development of these colleters.

The ultrastructural characteristics of $H$. stigonocarpa colleter secretory cells are similar to those of other species (Mohan and Inamdar 1986), especially in those of the inner stipule pairs (P3). The frequent association between ER and ribosomes may be related to enzyme production. Wall degradation, important in the formation of spaces by which secretion is released, constitutes evidence of enzymatic activity.

Formation of RER stacks as observed in H. stigonocarpa colleters was also reported by Zer and Fahn (1992) in Rosmarinus officinalis 
floral nectary. According to these authors this increase may be related to the lytic process of protoplast disintegration, which takes place after secretion.

The presence of sinuous wall cells in the outermost stipule colleters, was confirmed in several studied samples; this reduces the possibility of it being a technical artifact. This sinuosity may be attributable to cell wall weakening by enzymatic action. In this phase, rupture of the middle lamella was seen; this and the presence of RER and dictyosomes may be evidence of enzyme synthesis, which corroborates this hypothesis. Dissolution of the middle lamella of secretory cells as described in this study was also reported in colleters by Mohan and Inandar (1986).

The absence of pores or channels in the cuticle leads us to suppose that colleter secretion release occurs by cuticle rupture as the result of pressure exerted by secretion accumulated in the subcuticular space (Mohan and Inandar 1986, Paiva et al. 2001). This manner of colleter secretion release was also reported by Thomas and Dave (1989) and Paiva and Machado (2006).

Secretion accumulation in the subcuticular space in $H$. stigonocarpa colleters seems to promote cuticle expansion, which gives it a loose and flaccid aspect. Release of colleter secretion into the subcuticular space occurs way of by channels between the epithelial cells, as described by Thomas and Dave (1989) in Alamanda cathartica and Appezzato-da-Gloria and Estelita (2000) in Mandevilla species.

$H$. stigonocarpa colleters are not deciduous, a marked characteristic of these structures in several species and organs (Thomas 1991). This species shows early stipule senescence when the colleters still show secretory activity; thus colleter death may occur by desiccation due to stipule senescence and not to autolysis as seen by Mohan and Inamdar (1986) in Plumeria rubra. The presence of functional colleters at stipule abscission time shows similarity with the colleters of Caryocar brasiliense, another typical species of "Cerrado" vegetation (Paiva and Machado 2006).
The protective function of the shoot apex has been attributed to colleters (Mueller 1985, Thomas 1991). In addition, Dell (1977) and Rocha et al. (2002), report the function of cuticular transpiration reduction, which would result from secretion and deposit of resinous substances. The small volume of secretion of the $H$. stigonocarpa colleters makes it difficult to attribute a function to them, although the position and short life of these structures are in agreement with the hypothesis of shoot apex protection.

\section{ACKNOWLEDGMENTS}

The authors thank Fundação de Amparo a Pesquisa do Estado de São Paulo, FAPESP, for their financial support (Proc. 2001/003450 and 2000/12469-3) and the staff of Centro de Microscopia Eletrônica, Instituto de Biociências, UNESP, for their help in sample preparation.

\section{RESUMEN}

El género Hymenaea se caracteriza por una gran diversidad de estructuras secretoras, pero no hay informes de coléteres. El objetivo de este estudio es informar de su existencia en el género, y describir el origen y estructura de los coléteres en Hymenaea stigonocarpa Mart. ex Hayne. Procesamos muestras del ápice de brotes según los métodos generales para microscopio óptico, microscopio electrónico de barrido y microscopio electrónico de transmisión. Los coléteres están predominantemente en la parte adaxial de las estípulas, ocupando la base en una estrecha franja desde la vena media hasta mitad de la longitud de la estípula. En la parte abaxial, se concentran en la base y se restringen a los márgenes. Los coléteres surgen del protoderma; son alargados y en forma de bastoncillo. Sus cuerpos no poseen estratificación; sus células superficiales difieren de las internas solamente por la posición y la presencia de cutícula. Las células de los coléteres poseen paredes delgadas, citoplasma denso, núcleos grandes, muchas mitocondrias, retículo endoplasmático rugoso, y abundantes dictiosomas. Las pruebas histoquímicas con rojo ruteno mostraron compuestos pécticos en el citosol. En H. stigonocarpa, la distribución de los coléteres es compatible con la hipótesis de que protegen el ápice del brote. En esta especie, la protección es reforzada por la envoltura formada por los pares de la estípula. 
Palabras clave: vegetación de “Cerrado”, coléter, segregación, estípula, ultraestructura.

\section{REFERENCES}

Appezzato-da-Gloria, B. \& M.E.M. Estelita. 2000. Development, structure and distribution of colleters in Mandevilla illustris and M. velutina (Apocynaceae). Rev. Bras. Bot. 23: 113-120.

Dell, B. 1977. Distribution and function of resin and glandular hairs in Western Australian Plants. J. Proc. Royal Soc. West. Austr. 59: 119-123.

Fahn, A. 1990. Plant Anatomy. Pergamon, Cambridge, England. 588 p.

Johansen, D.A. 1940. Plant Microtechnique. McGraw-Hill, New York, USA. 523 p.

Karnovsky, M.J. 1965. A formaldehyde-glutaraldehyde fixative of light osmolality for use in electron microscopy. J. Cell Biol. 27: 137A-138A.

Lee, Y.T. \& J.H. Langenheim. 1975. A systematic revision of the genus Hymenaea (Leguminosae; Caesalpinioideae; Detarieae). Univ. Calif. Publ. Bot. 69: 1-109.

Lubbock, J. 1890. On stipules, their form and function. J. Linn. Soc. 28: 217-243.

Mohan, J.S.S. \& J.A. Inamdar. 1986. Ultrastructure and secretion of extrafloral nectaries of Plumeria rubra L. Ann. Bot. 57: 389-401.

Mueller, R.J. 1985. Determinate branch development in Alstonia scholaris (Apocynaceae), the plagiotropic module. Am. J. Bot. 72: 1435-1444.

O’Brien, T.P., N. Feder \& M.E. McCully. 1964 Polychromatic staining of plant cell walls by toluidine blue. Protoplasma 59: 368-373.

Paiva, E.A.S., H.C. Morais, R.M.S. Isaias, D.M.S. Rocha \& P.E. Oliveira. 2001. Occurrence and structure of extrafloral nectaries in Pterodon pubescens Benth. and Pterodon polygalaeflorus Benth. (FabaceaePapilionoideae). Pesq. Agropec. Bras. 36: 219-224.

Paiva, E.A.S. \& S.R. Machado. 2006. Colleters in Caryocar brasiliense (Caryocaraceae) ontogenesis, ultrastructure and secretion. Braz. J. Biol. 66: 301-308.

Robards, A.W. 1978. An introduction to techniques for scanning electron microscopy of plant cells, p. 343403. In J.L. Hall (ed.). Electron Microscopy and Cytochemistry of Plant Cells. Elsevier, New York, USA.

Rocha, J.F., L.J. Neves \& L.B. Pace. 2002. Estruturas secretoras em folhas de Hibiscus tiliaceus L. e Hibiscus pernambucensis Arruda. Rev. Univ. Rural, Sér. Ci. Vida 22: 43-55.

Roland, J.C. 1978. General preparations and staining of thin sections, p. 1-62. In J.L. Hall (ed.). Electron Microscopy and Cytochemistry of Plant Cells. Elsevier, New York, USA.

Schussler, E.E. \& D.J. Longstreth. 1996. Aerenchyma develops by cell lysis in roots and cell separation in leaf petioles in Sagittaria lancifolia (Alismataceae). Am. J. Bot. 83: 1266-1273.

Solereder, H. 1908. Systematic Anatomy of the Dicotiledons. Clarendon, Oxford, England.

Thomas, V. 1991. Structural, functional and phylogenetic aspects of the colleter. Ann. Bot. 68: 287-305.

Thomas, V. \& Y. Dave. 1989. Histochemistry and senescence of colleters of Alamanda cathartica (Apocynaceae). Ann. Bot. 64: 201-203.

Thomas, V. \& Y. Dave. 1990. Mode of secretion in the colleters of Alstonia scholaris (Apocynaceae). Phyton 30: 209-212.

Zer, H. \& A. Fahn. 1992. Floral nectaries of Rosmarinus officinalis L. structure, ultrastructure and nectar secretion. Ann. Bot. 70: 391-397. 